South African Journal of Geomatics, Vol. 4, No. 4, November 2015

\title{
Cadastral Systems Re-engineering in Urban Zimbabwe
}

\author{
Edward Kurwakumire ${ }^{1}$, Shelter Kuzhazha ${ }^{2}$ \\ ${ }^{1}$ Geomatics Department, Tshwane University of Technology, Pretoria, South Africa, \\ KurwakumireE@tut.ac.za \\ ${ }^{2}$ Gems Geoconnexions, Tzaneen, South Africa
}

DOI: http://dx.doi.org/10.4314/sajg.v4i4.6

\begin{abstract}
Land is undoubtedly the most important resource in any country as it contributes to economic development. The cadastre is a component of the land administration system (LAS) that is crucial for managing land. It is thus of importance for a nation to have both a functional cadastral system for determining parcel boundaries and a functional cadastral information system, for managing the land parcels. The cadastral survey system and cadastre in Zimbabwe are largely manual with even the lodgement of completed surveys for examination and approval still analogue. This has an impact on the time it takes to complete a land transaction. Land can ideally drive the economy yet part of the value is lost due to lengthy land transaction procedures. The land administration system is supposed to consist of value adding processes in which several actors interact in a workflow which creates new or transfers parcels. This workflow is associated with transaction costs, part of which can be employed for maintenance of the cadastral information system. This article presents business processes for the land development process in Zimbabwe but focusing on City of Gweru (CoG) and City of Mutare (CoM) municipalities as the major organisations under study. Municipalities in Zimbabwe are governed by the Regional Town and Country Planning Act, so such a single process and workflow model can fit into the cadastral information system of all municipalities in Zimbabwe with insignificant changes. The broader scope of this study is towards the design of a conceptual schema for automating the land administration system and particularly, the cadastre component, for municipalities in Zimbabwe. This study presents the workflows for the current land development system with CoG and CoM as the current focal points. Information on current automation efforts or reforms by other major municipalities to include Bulawayo, Kadoma and Kariba is also presented. The overall theme of this paper is to discuss cadastral reform through automation of cadastral processes in municipalities.
\end{abstract}

\section{Introduction}

The cadastre is a framework by which mankind relates to land, identify its respective units and uses according to (Bevin, 1999). This relationship to land changes as mankind and society evolve and as such 
the cadastre should be dynamic rather than static. Cadastral systems should be focused on efficient and timely processing of secure land transactions with improved access to land information. The cadastre and in particular, the whole land administration system (LAS), should adapt and be agile to the ever-changing needs of society. For the purposes of this study, a cadastral information system is a component of the LAS specialising in recording, managing and disseminating land information. The term cadastral information system will be used synonymously with land information systems.

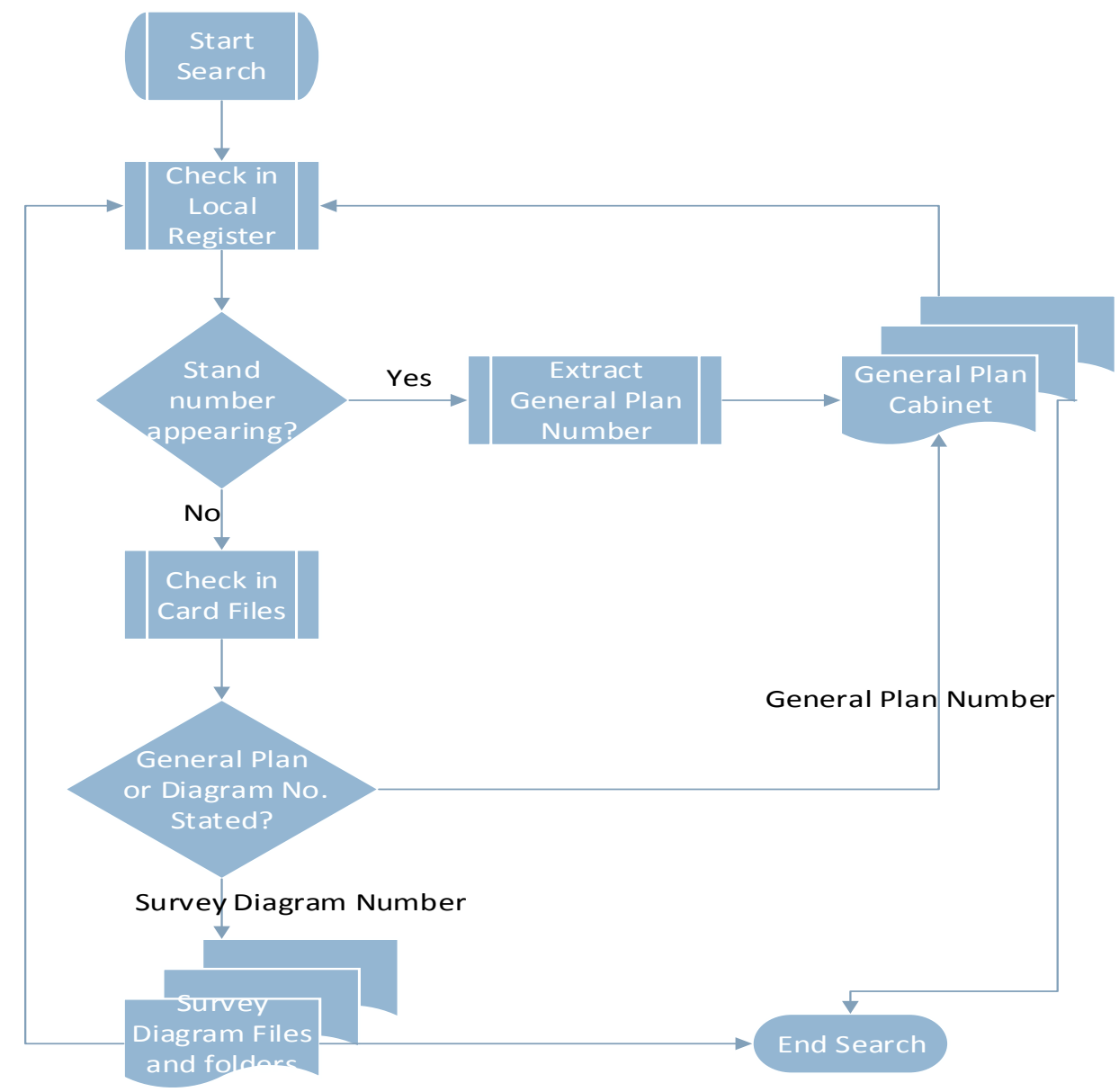

Figure 1. Information Access at CoM - Adapted: (Kurwakumire, 2007)

The Zimbabwean and South African cadastral systems have several similarities as they both have similar origins. Both systems originated from the Roman-Dutch law. Currently the major differences that can be perceived are the levels of cadastral reforms that have taken place to date in the different countries. The Zimbabwean and South African systems all comprise of separate deeds registry and cadastral offices. South Africa has more promptly adopted to utilising new technology for surveying and mapping. On the other hand Zimbabwe has been stagnant in adopting technology and in updating the surveying legislation to make the cadastral system more efficient. Figure 1 shows one of the manual systems implemented in 
City of Mutare for searching and retrieving cadastral information. The cadastral system in Zimbabwe has been static rather than evolving. Only recently in 2015, has there been a proposal to engage a consultant to focus on reviewing Zimbabwe's land surveying regulations in support of the Ministry of Lands and Rural Resettlement 2014 to 2016 action plan. This proposal came through from United Nations Development Programme and the review of regulations is scheduled to start on the $16^{\text {th }}$ of November 2015 should the services of an appropriate international consultant, who should be a professional land surveyor as well, be secured.

To date, the cadastral system in Zimbabwe is still largely analogue and could benefit from modelling and re-engineering of its work flows. The re-engineering improves the performance of the cadastre while modelling provides a systematic approach to land information systems development across municipalities. There is no need to reinvent the wheel but to adopt parts or sections of the models that have been developed in the land administration field. This is due to the fact that land administration systems can be highly context dependent. As a result, what works in one country does not necessarily work in another due to context which can include the socio-economic and political environment, culture, religion, social values and other local institutions. However, international models provide starting points and guidance towards the development of LAS and particularly the cadastral or land information systems modules. In this regard, it is worthy to take note of some international land administration models that have been developed to date as they assist in the design of future land based information systems.

The continuum of models can be traced from the land tenure model (Subject-Object-Right) (Henssen, 1995), cadastre 2014 (Kaufmann and Steudler, 1998), the Core Cadastral Domain Model (Lemmen et al., 2003; van Oosterom et al., 2006), the Social Tenure Domain Model (Augustinus et al., 2006; Lemmen, 2010) and currently the land administration domain model (Lemmen, 2012; Tjia and Coetzee 2013; Lemmen et al., 2012; Uitermark, 2012; van Oosterom et al., 2013) (see figure 2). The aim of these models was to provide a common platform, standards and mechanisms for developing nationwide land administration systems in an international domain. These systems need to be extensible and interoperable (Kurwakumire, 2013a) so that they can evolve to land administration systems of the future through enabling expansion and further upgrades. The Surveyor General's Department in Zimbabwe has already lost a system due to lack of upgrades and system maintenance resulting in the system becoming obsolete with all the land information. This system was implemented by SwedeSurvey through the Swedish government in the late 1990s and towards the turn of the century. It comprised of a Microsoft Access database for attribute information and watermark imaging database for storing scanned copies of survey diagrams and other documents but without geographic information systems functionality. This system aimed to achieve automation of cadastral survey records and improving access and management of 
cadastral information. This negatively affected the progression of the development of a digital cadastral system for Zimbabwe.

\section{Problem Context}

Several reforms are necessary for the Zimbabwean land administration system including automating the survey lodgement process, adoption of information and communication technology (ICT) based spatial data collection techniques (Kurwakumire and Chaminama, 2012) using information systems approach in operating and managing the cadastral and land registration process (Chimhamhiwa and Lemmen, 2001; Kurwakumire 2007; Kurwakumire, 2013a; Kurwakumire 2014) and automating the communal land administration system (Kurwakumire, 2013b). This study focuses on automating the urban cadastre with focus on municipalities and the land development process. This is done through presenting the workflows showing the static situation depicting the current procedures and then the reengineered workflows which encompass effectiveness through delivery within turn-around times. A future study will include the Surveyor General's Department (DSG) and the deeds registry into a broader land administration system (LAS).

\section{Research and Systems Development Paradigms in Land Administration}

The core of land administration systems is on land tenure which defines the relationship between mankind and land. Due to the need to improve efficiency of the cadastre and the advent of information and communications technologies (ICT), several cadastral reform measures have been implemented (see Figure 2) including automation of the cadastre and implementation of cadastre 2014. Initial automation activities were done municipality by municipality and country by country but without standards to base the systems development on. As a result, the cadastre 2014 'vision for future cadastral systems' (Kaufmann, 2002; Kaufmann and Steudler, 1998) was developed in 1998 with an aim of improving the efficiency and effectiveness of the cadastre through the development of a paperless cadastral offices as one of the objectives. New Zealand had in 1999, already made significant strides towards achieving the objectives of cadaster 2014 according to (Bevin, 1999). The objectives of Cadastre 2014 have been adopted by several nations to include Australia and New Zealand (Hirst, 2010) and Switzerland (Kaufmann et al., 2002) towards land administration systems development.

The cadastre 2014 vision was conceptualised through the core cadastral domain model (CCDM) (Lemmen et al., 2003; van Oosterom et al., 2006) which aimed at developing a common standard for cadastral systems development. Focus on the CCDM was on formal tenure systems yet within land administration (LA) research, there has been growing interest in pro-poor and unconventional practices to land administration (van der Molen, 2005). Pro-poor LA practices were modelled through the social 
tenure domain model (Augustinus, 2006) which was directed towards bringing all semi-formal and informal tenure arrangements into the formal management domain in order to promote better land administration and governance. The application of the social tenure domain model has been piloted in Ethiopia according to (Lemmen and Zevenbergen, 2010).

\section{LA systems development}

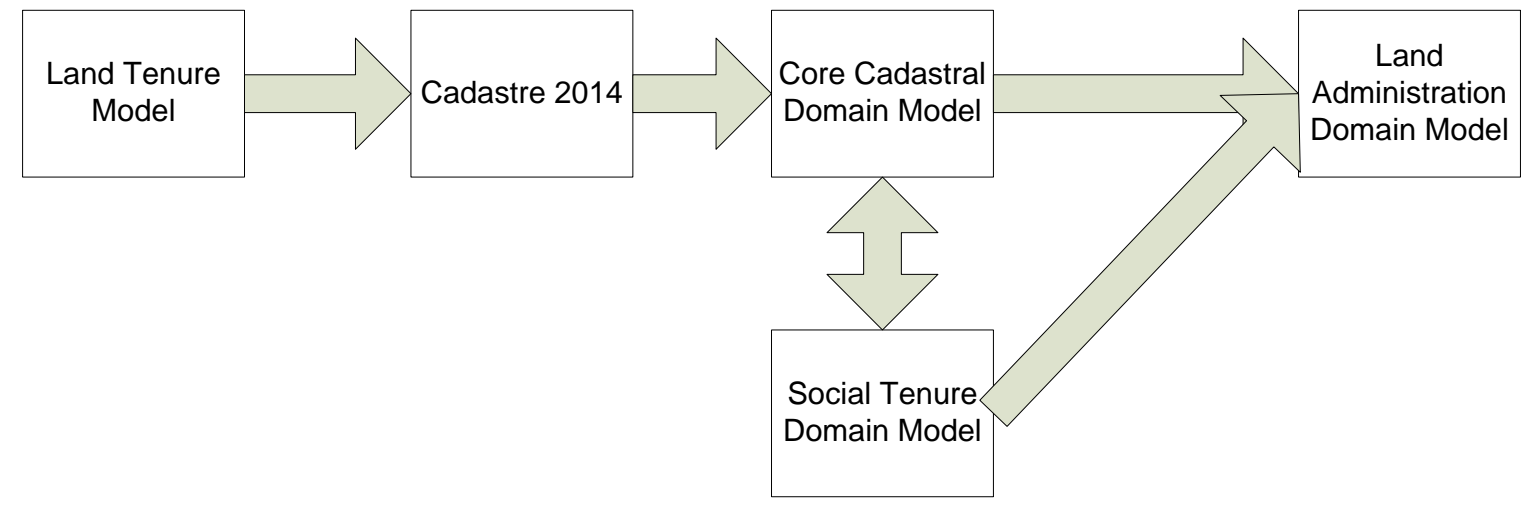

Research Paradigms

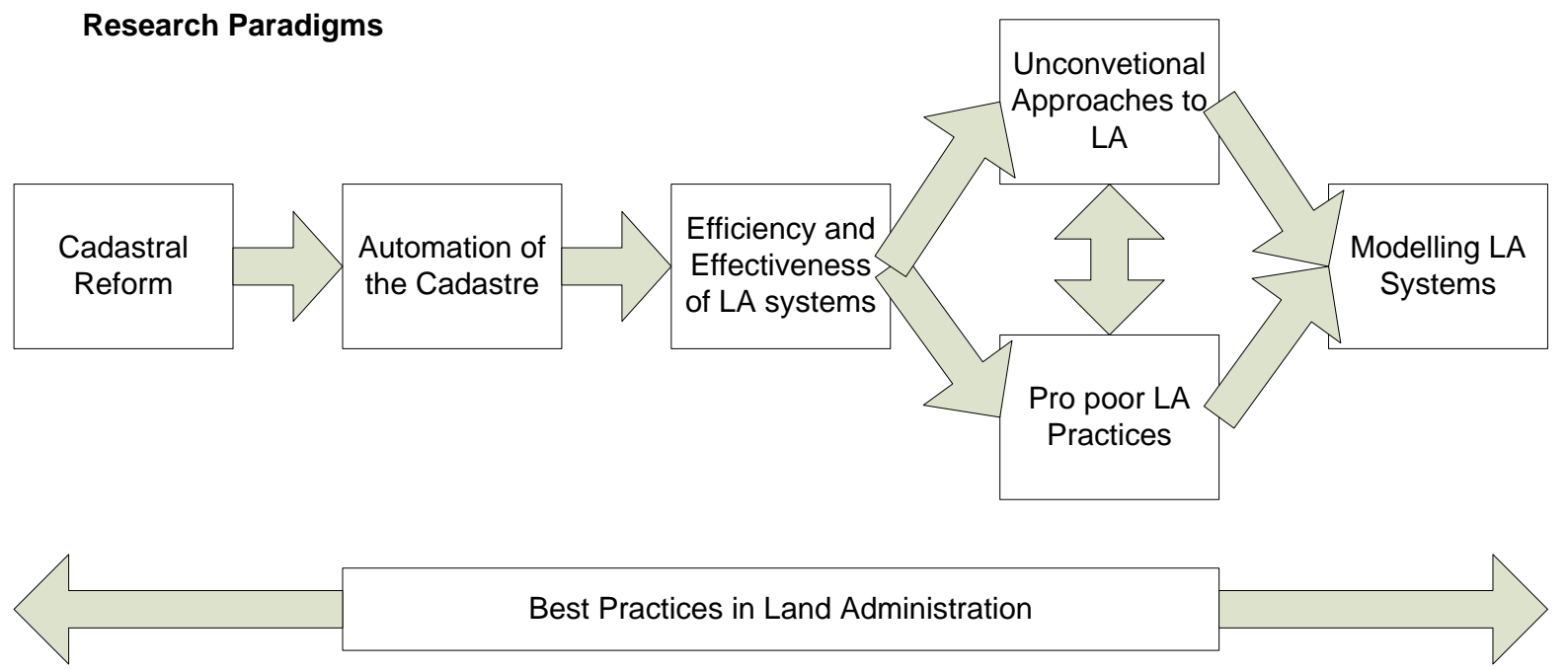

Figure 2. Land Administration Research and Systems Development Paradigms

To date, research within the land administration domain has focused on modelling land administration systems with the LADM as the most recent model for systems development published in 2012 (Tjia and Coetzee, 2013). Within the research and systems development paradigms, there has been a change in terminology from initially, cadastral systems to currently land administration systems. The wide range of research and systems development paradigms can be summarised as aimed at: (1) Improving the operational efficiency of the land administration systems, (2) Identifying and implementation of best practices in land administration and (3) Good governance in land. As a result, future cadastral systems should also focus on efficiency, best practices and good land governance. 


\section{Related Work}

According to the Economic Commission for Europe (2005), a "good land administration system guarantees ownership and security of tenure, aids in developing and monitoring land markets, ensures good governance in land and improves urban planning". The land administration system should be sustainable, affordable and accessible to the public while meeting the needs of its users or stakeholders. Zimbabwe needs a good LAS to support its property market and to provide up-to-date land information. Given the value of land and its contribution to a nation's economy, it is of vital importance to have an operational, efficient and effective land administration system. The system is not solely available for land transactions or managing land information, but should be usable by various sectors for spatial planning, local and national government and service delivery using the land parcel as the unit of analysis. Municipalities can use the land administration system to access fundamental datasets for planning, implementing and managing service delivery.

Hirst (2010) acknowledges the wide use of Cadastre 2014 internationally as a framework in cadastral systems development. Hirst discusses how Australia and New Zealand were meeting the objectives established by the cadastre 2014 vision but also looks at the relevance of the six statements from the vision 11 years later after publication of the cadastre 2014 document but in the Australian and New Zealand context. Hirst (2010) emphases the need of a new cadastral vision for 2030 so that countries can better align their cadastral reforms to past experiences, challenges and best practices.

Modern land information stakeholders and users desire efficient and timely access to spatial data (Mwajibuko, 2011). This is in the wake of the fact that real property information management is one of the dilemmas faced by the majority of African countries Zimbabwe included. Manual cadastres pose major problems as land information increases. These include lengthy access to public services, low service response rates, inadequate data security, loss of land information and corruption of service (Mwajibuko, 2011). A digital and networked land information system that integrates the deeds registry and cadastre can solve the aforementioned challenges while allowing remote and timely access to real property information by different stakeholders in various locations. A secure cadastral system brings stakeholder confidence to the land market.

Bennet et al., (2013) detail the importance of viewing land administration systems (LAS) as critical public good infrastructures. This is the same recognition that has been placed on spatial data infrastructures (SDI). LAS and SDI both form public infrastructures as they both make available public sector information (PSI) which should be widely accessible to the citizenry. PSI is a public good in the same manner as roads and telecommunications networks are. Spatial data can be viewed as a public good 
due to its wide and day-to-day use in various levels of government, private, non-governmental sector and

by the general public. Recognising LAS as critical public good infrastructures ensures availability of funding for their management and maintenance. The LAS would then be able to serve its purposes that include efficient land transactions and timely access to real property information by the public.

Tjia and Coetzee (2013) explore the application of the land administration domain model (LADM) in the improvement of the land information system (LIS) at the City of Johannesburg in South Africa. The LIS, after re-engineering, should then be able to integrate fundamental land information with other property information. This is achieved through the development of a LIS model based on the LADM conceptual schema. The LADM enables the exchange and maintenance of various spatial data sets by different departments and organisations.

Li et al., (2012) develop a cadastral domain model with an object to integrate real estate registration in China which facilitates exchange of cadastral information and effective land-use administration. The cadastral domain model developed integrates the spatial and legal aspects of land registration. It also serves the purpose of providing a conceptual schema for the development of a cadastral information system. Ali and Shakir (2012) detail the implementation of a geographical information system technology based LIS in Pakistan in an effort to automate and improve the efficiency of the cadastre.

The relevance of the literature discussed in this and previous sections is to bring out the importance of proper, functional and automated LAS in support of various land related activities. Of importance is to consider the LAS as a public good infrastructure so that there is always funding to support its development, operation and continued maintenance. The system needs to be affordable and accessible to all stakeholders and particularly, the ordinary citizen. The development of the LAS benefits from international models such as the LADM which can be tailored to fit the situations of different country LA contexts. It is vital not to only transfer the static situation of land tenure, but also to consider how society has changed or evolved through continued modernisation when modelling LAS. Modernisation can result in new forms of land tenure and a future LAS should be able to accept and handle new tenure arrangements showing some level of adaptation from the system. It is worthy to consider if the methods for determining property boundaries for land registration purposes should also evolve and whether or not to employ fixed or general boundaries. All these aspects need to be considered when making reforms on the current cadastral system in Zimbabwe in order to development a better and more functional LAS.

\section{Land Development in Zimbabwe}

This study is among the first in a series of studies aimed towards the developments of a schema for the cadastre and land registry in Zimbabwe. The focus of this study is at municipality level as 
municipalities in Zimbabwe have largely manual cadastral processes (Kurwakumire, 2013a) yet they play a significant role in land transactions and the management and provision of land information to different stakeholders within and outside the land development process. The larger study is towards the development of a LADM profile which covers Zimbabwe as a whole.

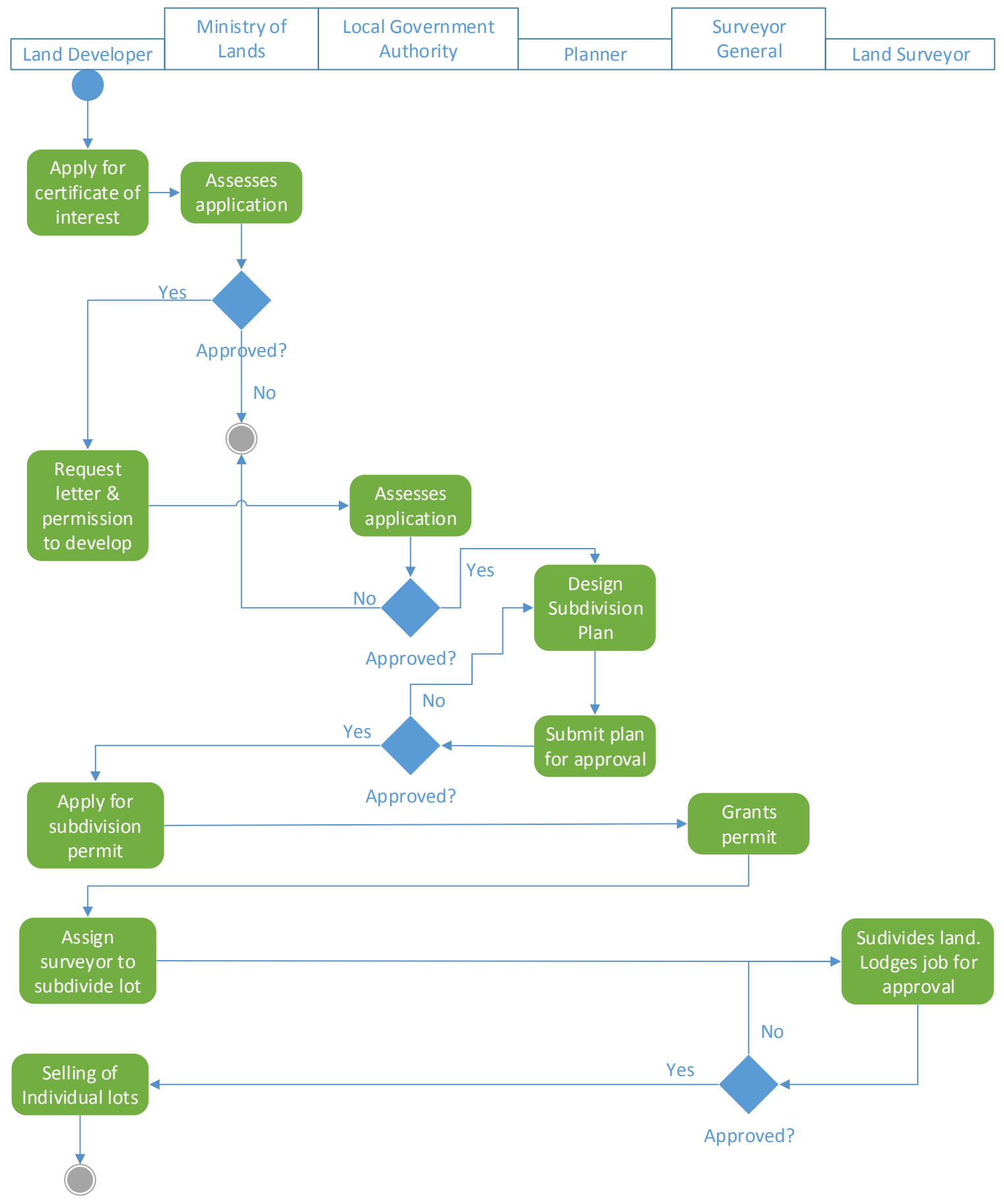

Figure 3. Land Development Activity Diagram 
The model for cadastral information systems design for municipalities should facilitate exchange of information between government, private and non-governmental sectors comprised of organisations with direct or indirect interests in land. Systems used by municipalities should be able to update directly into the national system that can be ideally hosted by the Surveyor General's Department. This study as a first attempt, identifies some processes or activities, stakeholders and entities significant for reengineering the cadastre so that the future land administration model is based on an efficient cadastre. For the purposes of this study, City of Gweru and Mutare are used as the major point of references due to the authors' in-depth knowledge and continued interaction with personnel and activities from the municipalities. Gweru is the provincial capital in Midlands while Mutare is the provincial capital in Manicaland province. Mutare is the $4^{\text {th }}$ largest while Gweru is the $5^{\text {th }}$ largest major city in terms of population but Gweru is larger than Mutare in terms of spatial extent.

The land development process starts with a land developer who has to apply for a certificate of no interest from the Ministry of Lands (see figure 3). This is a quality control measure for checking if any national or public interests exists or are planned on the land in question. If there are no interests then the land developer requests for permission to develop the land from the local government authority (LGA). The LGA can be a municipality such as City of Gweru if the land is within the municipality's jurisdiction or the department of physical planning when the land is outside the municipality. The local government authority (LGA) assesses the application or request against city bylaws, zoning regulations and public interests. If the application is approved, the applicant can then, through a town planning officer, design a subdivision plan and submit to the LGA for approval. Upon approval of the subdivision plan, the applicant or land developer requests a subdivision permit for the surveyor general's department (DSG) and an instruction to survey the land in question. The applicant then assigns a registered or licensed land surveyor to survey the land according to the subdivision plan. Upon completion, the survey records are lodged at the DSG for approval after which the land developer can sell individual properties with or without some improvements erected. In order for the individual property buyers to get title documents, they have to go through the conveyancing procedure which is not depicted on figure 3 . The land developer has to deliver a minimum number of public services before development of the land by individual owners can commence. These include roads, water and sewer system.

\section{Re-engineering the Land Development Workflow}

Figure 1 depicts the information access protocols based on the manual cadastral system at City of Mutare (CoM) presented in (Kurwakumire, 2007). The cadastre is comprised of a register or list which contains the majority of parcels within the municipality. If the stand or parcel number is available in the register, then the general plan number is noted and the data seeker uses it to extract the general plan from the filing cabinet, assuming that the plan is not in use elsewhere within or outside the survey department. 
The survey department is the custodian of the data. Since the register is a hardcopy list, there is no mechanism for adding new parcels in a sequential manner, so they are recorded on card files which are stored separately. The reference of the general plan or survey diagram is also given on the card files. All subdivisions and consolidations where in the past recorded on the card files.

Figure 4 presents a database approach that transforms the workflows based on business processes depicted in figure 3 in form of a sequence diagram. This re-engineering process improves the processes of data access, sharing and exchange within and outside the municipality. Within the database approach all data is digital and stored in a cadastral or land information system (LIS) database server. There is a land information client which facilitates communication between remote and desktop clients and the database server using client-server technology.

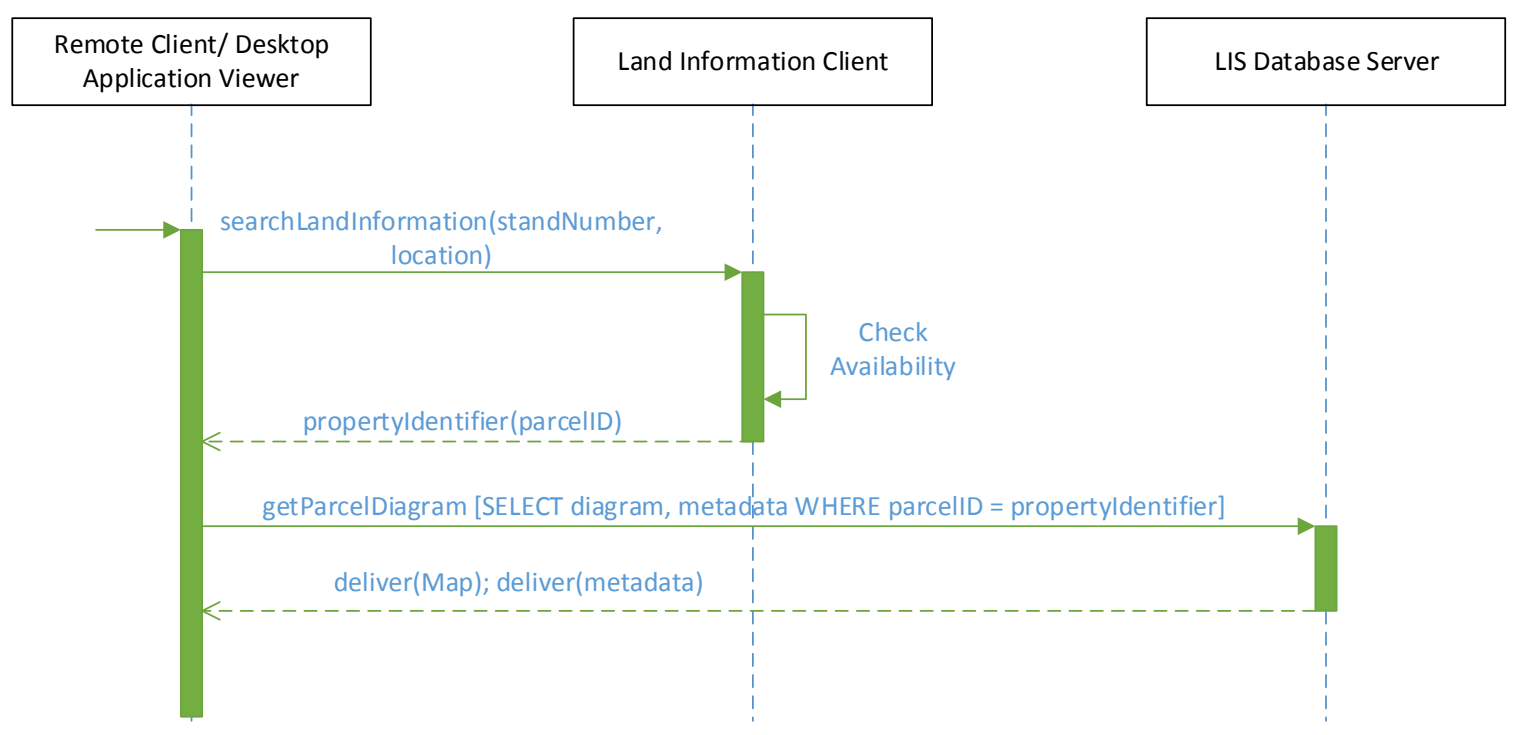

Figure 4. A database approach to land information retrieval

A data user enters a stand number and location on the remote or desktop client. The land information client checks if the stand number is captured in the system. This returns a unique property identifier namely the parcelID which is also a primary key (PK) that can be used to uniquely access the record from the database. On confirming the parcelID with the initial stand number and location, land information is then requested from the LIS database server. The map and metadata relating to the map are then delivered in a timely fashion as the ultimate result of the data search. However, this requires the system to be operational in real time and without interruption. Considerable internet bandwidth is required at the user's work station. 
South African Journal of Geomatics, Vol. 4, No. 4, November 2015

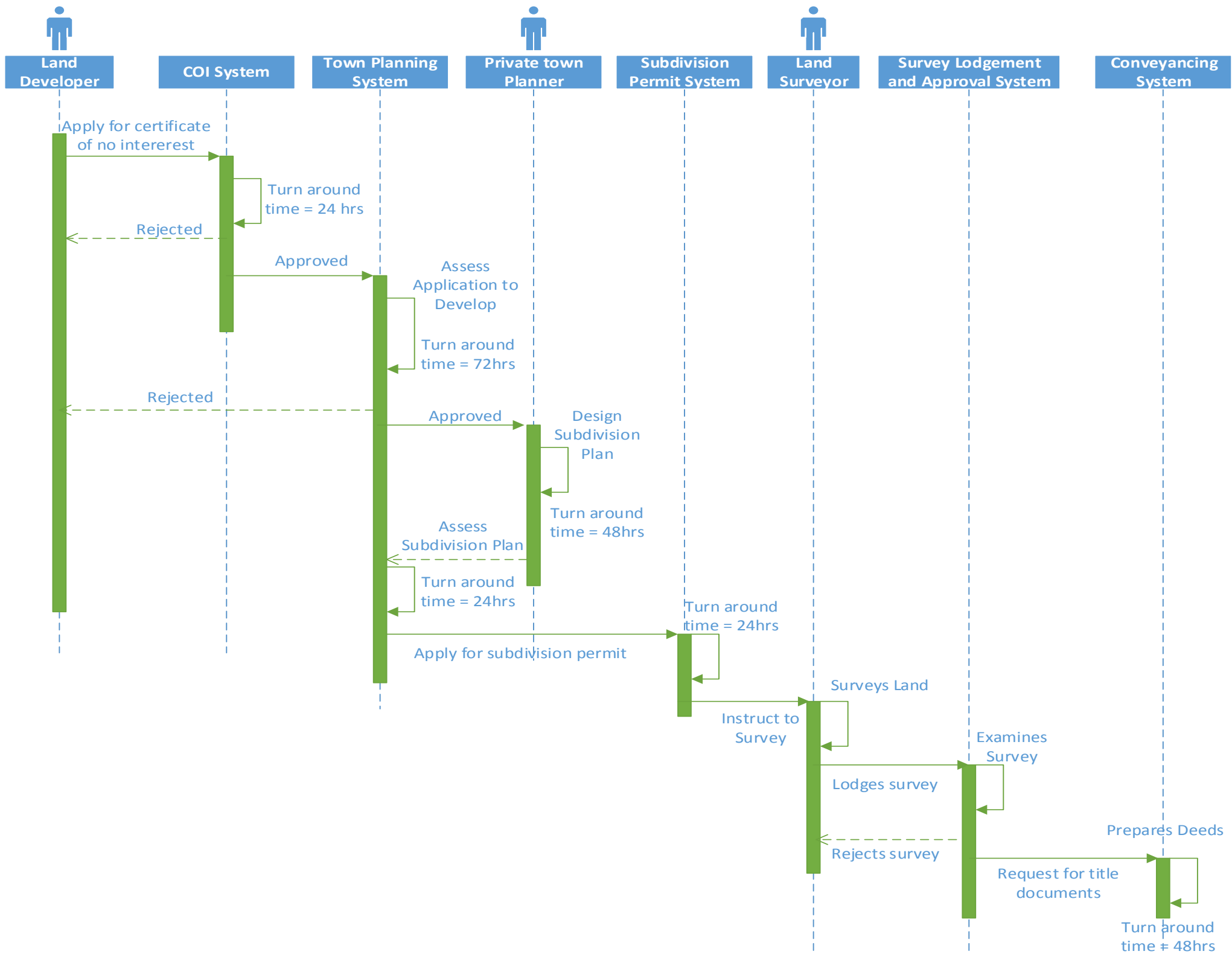

Figure 5. Reengineering the Land Development Workflow 
Figure 5 attempts to automate the land development business processes presented in figure 3 through the introduction of several information systems within the various involved departments. These systems include: (1) The conflict of interest (COI) system housed by the ministry of lands and rural resettlement, (2) The town planning system (TPS) housed by the local government authority, (3) The subdivision permit system housed by the surveyor general's department (DSG), (4) The survey lodgement and approval system (SLA) housed also by the DSG and (5) The conveyancing system housed at the deeds registry. As a result, the Ministry of Lands and Rural Resettlement, Municipality or Department of Physical Planning, Surveyor General's department, Land Developer, Land Surveyor and Town Planner are the major stakeholders relevant for this cadastral information system solely based on the land development process. These stakeholders need to cooperate and interact in order for the land development process to progress smoothly and effectively. The Ministry of Lands and Rural Resettlement, Municipality and the Surveyor General's department are also custodians of their respective systems and internal value chains but are also part of the integrated cadastral information system.

The intention of these systems in figure 5 is to manage jobs submitted, the workflow and clear the backlog. The systems should not be viewed as single discrete systems but one large integrated system. What is presented in figure 5 are the respective modules of the cadastral information system that are used by each actor or stakeholder in the land development process. Figure 5 also show the maximum turn around times for a particular transaction in the land development process in an effort to improve the efficiency and effectiveness of the overall land development supply chain.

\section{Towards a conceptual schema for modelling LAS}

In order to improve the operational efficiency and effectiveness of the cadastre, municipalities in Zimbabwe need to migrate to a systems approach based on recommended models within the land administration domain, for example, the land administration domain model (LADM). However, to ensure that there is readiness for implementation of the LADM, there is need to meet the objectives outlined in the six statements from Cadastre 2014 document. There is need for a modular approach to systems development which ensure interoperability and extensibility. The systems in future should be integrated into one large national land information system. This section introduces the major classes that are required for the land information system development to include Right: $\{\mathrm{PK}=$ rightID $\}$, Parcel: $\{\mathrm{PK}=$ parcelID $\}, \quad$ propertyType: $\{\mathrm{PK}=$ propertyTypeCode $\}, \quad$ Subject: $\{\mathrm{PK}=$ subjectID $\}$, landuse: $\{\mathrm{PK}=$ zoningID $\}$ and propertyRestrictions: $\{\mathrm{PK}=$ propertyRestrictionsCode $\}$. When mapping these classes to the LADM, they translate to Right = LA_RRR, Parcel = LA_SpatialUnit, propertyType $=$ LA_BAUnit and Subject = LA_Party. According to the LADM standard, the LA_RRR class contains all rights, responsibilities and restrictions while LA_SpatialUnit contains all land objects. Different types of real property that exists on the spatial unit are mapped though the LA_BAUnit class. The different 
types of legal persons with rights to land are mapped through the LA_Party class. In this regard, the LADM gives direction and guidelines in the development of a country profile for land administration systems. The schema for systems development is not designed at this point in time but rather is future work to build on the processes envisaged in figures 3 to 5 .

The most abstract relationship in the design is the connection between the person, land and right classes which define land tenure. There is need to be comprehensive in specialisations of what constitutes land objects, person types and right types. The aim is to develop a land administration system which can accommodate virtually all types of land holding, for different kinds of owners (natural and non-natural) and various types of land objects (point parcels, polygon parcels and multi-polygon parcels). The model should serve not only cadastral needs but should provide data relevant for the real estate industry and for the economic development of the nation. Thus there is need to incorporate real property information and other socio economic data to enable land administrators and policy makers to make more informed decisions.

The right class will have two major classifications of rights which are public and private. Within public rights there is non-excludability meaning, the land or property in question is meant for public use or has a public interest vested in it. Private rights exclude the public from enjoyment of use of the land or property in question. The right connects the person (subject) to land (parcel). The subject class also has two major classifications of a natural and non-natural person. This classification is done to cater for individuals, families, companies and any other organisations or corporations that exist. The parcel class considers polygon and point parcels and is closely related to land use and property restrictions. Property type details the nature of the property, that is, whether it is land only, land and buildings or land including some other improvements or infrastructure. The property restrictions reveal the existence of private rights in which the public may be excluded. In this context property may be privately or publicly owned. The restrictions can also relate to servitudes which are used by municipalities to deliver services such as water and sanitation.

\section{Current Automation Efforts in Zimbabwe}

Currently through an initiative from the German Society for International Cooperation (GIZ), the majority of major municipalities are initiating the use of geographic information systems (GIS) to support some strategic objectives of their operations. These municipalities include Harare, Kadoma, Kariba, Gweru, Chinhoyi, Norton and Bulawayo. The initiative from GIZ is to link water meter readings and billing system to GIS. Meter readings will be recorded as GPS points with data loggers. When these readings are synchronised with billing information, the city can monitor water demand against suburbs 
and households actually paying water bills. The city can monitor consumption, faulty water meters and even pipe leakage. However, the GIS use is still at grass root level whereby use is mostly centered at data capture through digitizing. Within Gweru City council, the GIS is housed under the Surveying section while in Bulawayo under Water Engineering.

City of Bulawayo is currently at the forefront in terms of GIS use. The city is performing data entry through digitizing from google earth imagery and existing hardcopy data sets. Currently City of Bulawayo has now digitized $80 \%$ of data covering Bulawayo. This data includes property boundaries, sewer and water lines, water meters, cemeteries and council installations. The city is working towards developing a webGIS for use by all departments within the municipality. Kadoma and Gweru municipalities have had GIS training but are still starting up in terms of use. Kariba has no survey section but is engaging interns to work on GIS related activities. City of Kariba is already linking GIS to the billing system. The major positive outcome of the GIZ initiative from a land administration point of view, is that, there will be creation of the majority of base data sets to include property boundaries, roads and water network for use in the dedicated future cadastral information system for Zimbabwe. The municipalities listed in this section are on their way towards attaining the objectives of statement four of Cadastre 2014 on the abolishment of paper and pencil cadastre through the creation of digital data and information technology based procedures for storage and management of cadastral information.

\section{Conclusions}

This study describes some business processes for access to cadastral data as well as the land development process within municipalities in Zimbabwe which facilitates land transfers and change in rights or interests. The workflow for data access is re-engineered using a sequence diagram which shows a database approach to information access. There is need to add the transaction times and costs to the land development business processes to clearly depict the land development workflow map in Zimbabwe. This can be transformed into the value chain process of the land administration system in municipalities. This map can be used to re-engineer the cadastral process before the design of an information systems based land administration schema. The study identifies some key classes that can be used in developing a conceptual schema for cadastral or land information systems in Zimbabwe. The schema will have its core on the land tenure model which emphasises the subject, object and right as the major entities. The schema will be designed based on the land administration domain model in order to ensure interoperability of systems from different departments. The improvement of the land administration system is the cadastral reform activity of the near future in Zimbabwe while complying with international domain models and standards. Building a conceptual schema based on the LADM ensures interchange 
South African Journal of Geomatics, Vol. 4, No. 4, November 2015

and exchange of land information between different stakeholders involved in land related activities and also to the public.

\section{References}

Ali, Z \& Shakir, M 2012, 'Implementing GIS-Based Cadastral and Land Information System in Pakistan', Journal of Settlements and Spatial Planning, vol. 3, pp. 43-49.

Augustinus, C, Lemmen, C, \& van Oosterom, P 2006, 'Social Tenure Domain Model: Requirements from the Perspective of Pro-Poor Land Management', 5th FIG Regional Conference: Promoting Land Administration and Good Governance. FIG: Accra, Ghana.

Bennett, R, Tambuwala, N, Rajabifard, A, Wallace, J, \& Williamson, I 2013, 'On recognizing land administration as critical public good infrastructure', Land Use Policy, vol. 30, pp. 84-93.

Bevin, T 1999, 'Cadastre 2014 Reforms in New Zealand', New Zealand Institute of Surveyors \& FIG Commission VII Conference \& AGM Bay of Islands, 9-15th October 1999

Chimhamhiwa, DA \& Lemmen, C 2001, 'Performance analyses of cadastral processes: a case study of the process of subdivision in Zimbabwe', International Federation of Surveyors: Available at: www.oicrf.org.

Economic Commission for Europe 2005, 'Land Administration in the UNECE Region - Developing trends and main principles', United Nations, ECE/HBP/140, Geneva 2005

Henssen, JLG 1995, 'Basic principles of the main cadastral systems in the world', Proceedings of the one day seminar of FIG Commission 7 - Vision on Cadastre 2014. Delft: The Netherlands.

Hirst, B 2010, 'Cadastre 2014 - Australia and New Zealand, now and the future', FIG Congress 2010: Facing the Challenges - Building the Capacity, Sydney, Australia, 11-16 April 2010

Kaufmann, J 2002, 'Cadastre 2014 - A Vision on future Cadastral Systems', 1st Congress on Cadastre in the European Union. Granada: Spain.

Kaufmann, K, Gubler, E, Glatthard, T, \& Steudler, D 2002, 'Swiss Cadastre: Cadastre 2014 for Sustainability', FIG XXII International Congress, Washington, D.C. USA, April 19-26, 2002

Kaufmann, J \& Steudler, D 1998, 'Cadastre 2014 - A Vision for a Future Cadastral System', Working Group 1 of Commission 7, International Federation of Surveyors, Switzerland

Kurwakumire, E 2007, 'The Cadastre as a tool for Land Management-Economic Reform?', Strategic Integration of Surveying Services: FIG Working Week 2007. Hong Kong SAR: China.

Kurwakumire, E 2013a, 'WebGIS Enabling Information Sharing in Local Government', South Africa Surveying + Geomatics Indaba (SASGI) Proceedings 2013, Kempton Park: South Africa.

Kurwakumire, E 2013b, 'Towards the design of a pro-poor land adjudication procedure for communal land', South Africa Surveying + Geomatics Indaba (SASGI) Proceedings 2013, Kempton Park: South Africa.

Kurwakumire, E \& Chaminama, N 2012, 'An Analysis of Data Handling Techniques in Zimbabwe', FIG Working Week 2012 - Knowing to manage the territory, protect the environment, evaluate the cultural heritage. Rome: Italy.

Kurwakumire, E 2014, 'Digital Cadastres Facilitating Land Information Management', South African Journal of Geomatics, vol. 3, no. 1, pp. 64-77

Lemmen, C 2010, 'The Social Tenure Domain Model: A Pro-Poor Land Tool: FIG Publication No 52', In H Uitermark \& C. Lemmen. (eds.), International Federation of Surveyors, Copenhagen: Denmark, ISBN 97887-90907-83-9. 
Lemmen, C 2012, 'A Domain Model for Land Administration', ITC - Tu Delft, The Netherlands. ISBN 978-9077029-31-2.

Lemmen, CHJ \& Zevenbergen, J 2010, 'First experiences with a high-resolution imagery-based adjudication approach in Ethiopia', in K Deininger, C Augustinus, S Enemark and P Munro-Faure (eds.), Innovations in Land Rights Recognition, Administration, and Governance, The World Bank, pp. 122-133.

Lemmen, C, Uitermark, H \& van Oosterom, P 2012, 'The Final Steps Towards an International Standard for Land Administration', FIG Working Week 2012 - Knowing to manage the territory, protect the environment, evaluate the cultural heritage. Rome: Italy.

Lemmen, C, van Der Molen, P, van Oosterom, P, Ploeger, H, Quak, W, Stoter, J \& Zevenbergen, J. 2003, 'A modular standard for the Cadastral Domain', Digital Earth.

Li, M, Zhu, X, Shen, C \& Chen, D 2012, 'The development of cadastral domain model oriented at unified real estate registration of china based on ontology', ISPRS Annals of the Photogrammetry, Remote Sensing and Spatial Information Sciences, vol. 1, pp. 209-215.

Mwabujoko, EA 2011, 'Accessibility of lands information to authorised remote stakeholders in Tanzania', Article under review for the International Journal of Spatial Data Infrastructures Research, Submitted February 2011.

Tjia, D, \& Coetzee, S 2013, 'Application of the Land Administration Domain Model to the City of Johannesburg Land Information System', South African Journal of Geomatics, pp. 260-278.

Uitermark, H 2012, 'Status of the LADM Standardisation Process within ISO/TC211', Workshop on LADM from Research to Implementation. Rotterdam: The Netherlands.

van der Molen, P 2005, 'Unconventional Approaches to Land Administration: A first attempt for an international research agenda', ITC Lustrum Conference on Spatial Information for Civil Society. Enschede: The Netherlands.

van Oosterom, P, Lemmen, C \& Uitermark H 2013', ISO 19152:2012, Land Administration Domain Model published by ISO', FIG Working Week 2013. Abuja: Nigeria.

van Oosterom, P, Lemmen, C, Ingvarsson, T, van der Molen, P, Ploeger, H, Quak, W, Stoter, J \& Zevenbergen, J 2006, 'The core cadastral domain model', Computers, Environment and Urban Systems, vol. 30, pp. 627-660. 